\title{
MINIMIZING ECONOMICAL LOSSES WITH THE HELP OF "REAL-TIME" ALGAL SURVEILLANCE
}

\author{
Edna Granéli ${ }^{1}$ \\ Christina Esplund ${ }^{1}$ \\ Elin Lindehoff ${ }^{1}$ \\ Andreas Brutemark ${ }^{2}$ \\ ${ }^{1}$ LnuC EEMiS, Linnaeus University, Kalmar, Sweden \\ ${ }^{2}$ Novia University of Applied Sciences, Ekenäs, Finland
}

\begin{abstract}
Cyanobacterial blooms covering almost the entire Baltic Sea is a yearly feature during JulyAugust. For the tourism industry at Öland island, SE Sweden, the economical losses during the summer 2005 amounted to 17-23 million euros. Remote sensing satellite images show that all the Öland beaches are covered with decomposing algae. In reality, these blooms rarely reach the western side of the island. To more accurately inform the public on the quality of the water for swimming, with the help of volunteers, a daily real-time surveillance of the algal densities on the beaches was performed. The volunteers (from 15 years old to pensioners) were trained at the Linnaeus University, from simple laboratory techniques, to more complicated ones such as identification and enumeration of the toxic cyanobacteria species. By latest 9.00 a.m., the public had access to information on the algal situation on 17 beaches. We could show that: 1) although remote sensing images showed Öland being surrounded by the blooms, our surveillance showed no algal accumulations on the beaches 2) that the real-time warning system boosted public confidence in the local water quality and during the first "Miss Algae"-summer 2006, the economical losses by the tourism industry turned in profits, the gain amounting to 17 million euros, 3) this kind of real-time surveillance is economical feasible due to low-costs involved, but also, the project has a great social value for the volunteers who mostly were pensioners. The volunteers who participated in "Miss Algae" had a good knowledge about the area they monitored (as their houses are located nearby) and could disseminate knowledge to the public in these areas. This kind of project also render a lot of interest regional, national and international, and can be used in advertising campaigns to increase tourism in the areas affected by algal blooms.
\end{abstract}

\section{KEYWORDS}

Harmful algal blooms, Economical losses, Real-time surveillance, Volunteers.

\section{SCIENTIFIC BACKGROUND}

In Sweden, satellite pictures showing cyanobacterial blooms covering almost the entire Baltic Sea during July-August, are daily placed by the Swedish Meteorological and Hydrological Institute 
(SMHI) in their homepage [1]. The media report these events in a very negative way scaring tourists from the beaches. The economical losses by the tourism industry for the island of Öland, during the summer of 2005 amounted to 17-23 million euros. As remote sense satellite images have a low resolution, from these pictures, it looks like all the Öland beaches are covered by the blooms.

In reality, these blooms rarely affect the western side of the island, and even the east side, when affected, can within hours be suitable again for swimming as wind and currents rapidly move these blooms offshore.

Since the problem with increased algal blooms will probably remain for years to come, in order to decrease the economical losses suffered the tourism industry (as tourists avoid the beaches when hearing such negative reports), we started at the Linnaeus University (former Kalmar University, HiK), in 2006 a pilot project called "Miss Algae", which continued until 2009.

The project involved the reporting of an intensive daily real-time algal surveillance of the beaches in our homepage (www.hik.se/alg). Several types of information (photographs of: the beach, the water, and a filter containing the algal cells), were posted at the homepage by latest 9.00 a.m. each day. Besides, also daily posted were illustrations consisting of colored squares and checked boxes beside the beach names, indicated in green when the beaches were "algal free" and turned to yellow or red if algal blooms reached the beaches. It was hoped that this information would generate sufficient confidence for the tourists to return to these beaches.

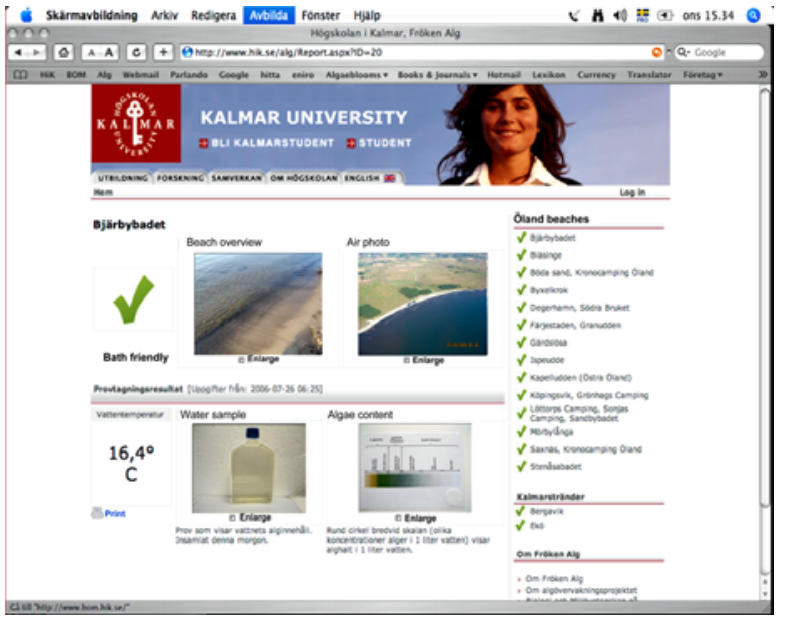

Figure 1. An example on how a specific beach looked each morning as seen on the Linnaeus University homepage (www.hik.se/alg)

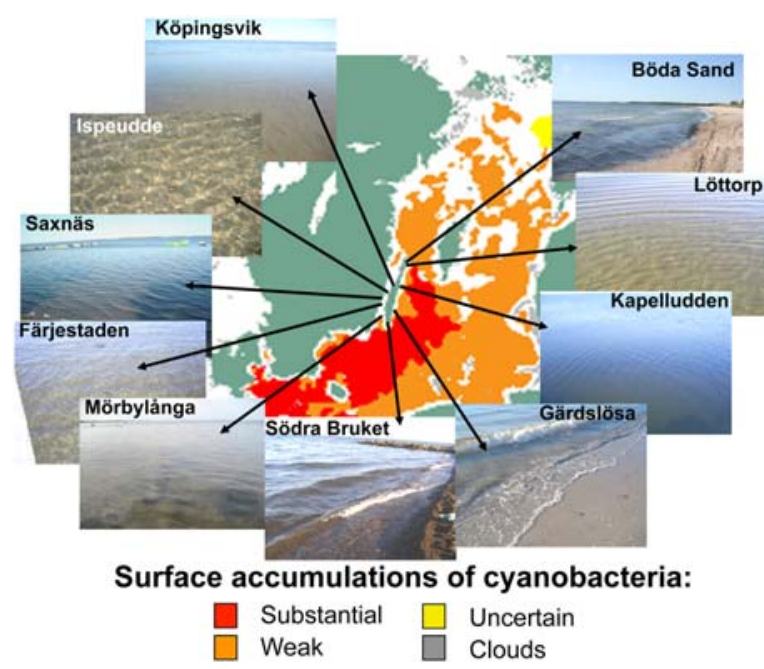

Figure 2. Pictures showing that the beaches in Öland were algal free on the same day the remote sensing image showed that the bloom reached the island. 


\section{HOW WAS THE DAILY HAB SURVEILLANCE DONE?}

Volunteers where recruited in May 2006 (pensioners, youth, camping-place workers, etc.) and got necessary training in simple research techniques at the University of Kalmar. Daily, early in the morning (between 6.00 and 7.30 a.m.), during July and August, at least one volunteer per beach, took photos of the beaches and measured physical data (salinity, water temperature, cloudiness and winds). Together with the data, three photos were sent to the responsible scientist at Kalmar University: 1) of the beach; 2) of a water sample in a clear bottle $(\approx 1$ liter $) ; 3)$ of a filter with the algae concentrated from 1 liter of seawater placed beside a color scale, ranging from low to high densities of cyanobacterial cells.

We, the scientists after validating the data placed, before 9.00 a.m., the photographs on the homepage, (www.hik.se/alg), and wrote a recommendation if the beach was fit or not for swimming (see Figure 1).

Also ten inverted microscopes equipped with a digital camera were placed around the island, so the volunteers could, in case of a bloom, send photos of the algal species for the scientist at the Kalmar University to count and identify.

\section{HOW DID THE REAL-TIME ALGAL SURVEILLANCE WORK?}

As we hypothesized, we could show that the Öland beaches were not affected by cyanobacteria accumulations even when the satellite images showed that this was the case. Even when heavy cyanobacteria blooms covered the entire Baltic proper during July and August 2006-2009 (see Figure 2), the Öland beaches had not been reached by the blooms.

Even when, on few occasions, some of the beaches where reached by cyanobacteria, we could very rapidly, with the help of the microscope photographs and fast transport of algal samples for us to count, inform the public that the toxin producing species Nodularia spumigena was in very low/undetectable cell densities, not in enough numbers to close the beach. The major part of these blooms were made up by Aphanizomenon sp. and Anabaena sp. The highest cell densities for Nodularia spumigena (at Byxelkrok, 10 July 2006) was still far below harmful levels.

During 2006, the volunteers also sampled water every third day for analyses of nutrients (nitrate, ammonium, phosphate, and silica), phytoplankton counts, chlorophyll, and cyanobacteria pigments (phycocyanin and phycoerythrine).

After August, the volunteers continued taking samples for nutrient analyses once a month until the end of June 2007. Thus the project was also aiming to generate data on the input of nitrogen and phosphorus to the coastal areas around the Island. The idea was that the generated information would become a data series to be used as e.g. for planning of wetlands in order to reduce $\mathrm{N}$ and $\mathrm{P}$ input on the areas suffering the highest input of these nutrients. Between 2007-2009, however, the planned data series on nutrients, cell counts and pigment values had to be taken out from the project due to less funding.

The first year results from the project were presented as a poster at the " $12^{\text {th }}$ International Conference on Harmful Algae" in Copenhagen 2006, and were met with great interest by the international researchers working on monitoring, mitigating and forecasting of harmful algal blooms. 


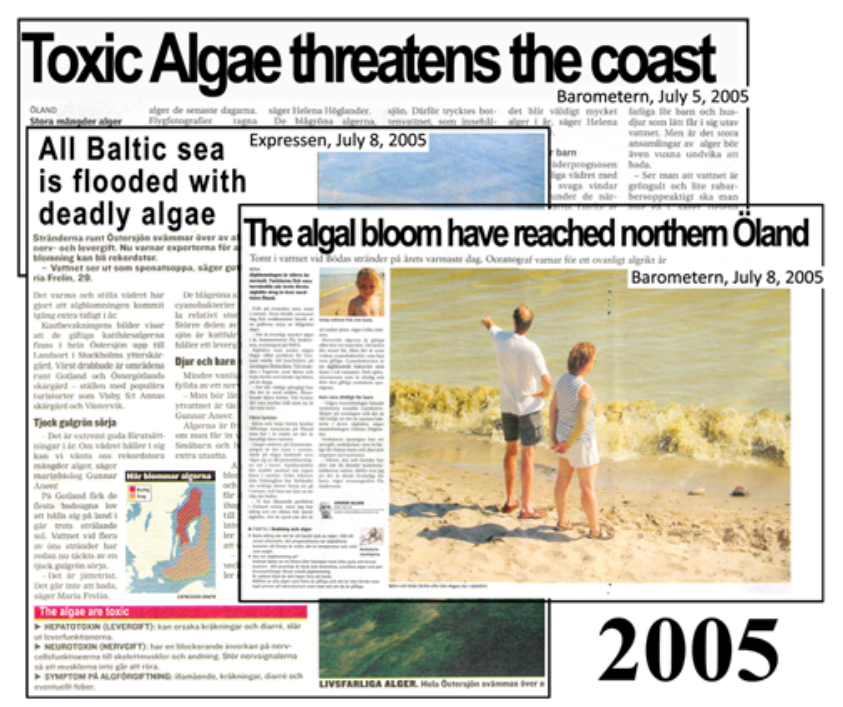

Figure 3. "Catastrophic"

newspaper headlines from 2005.

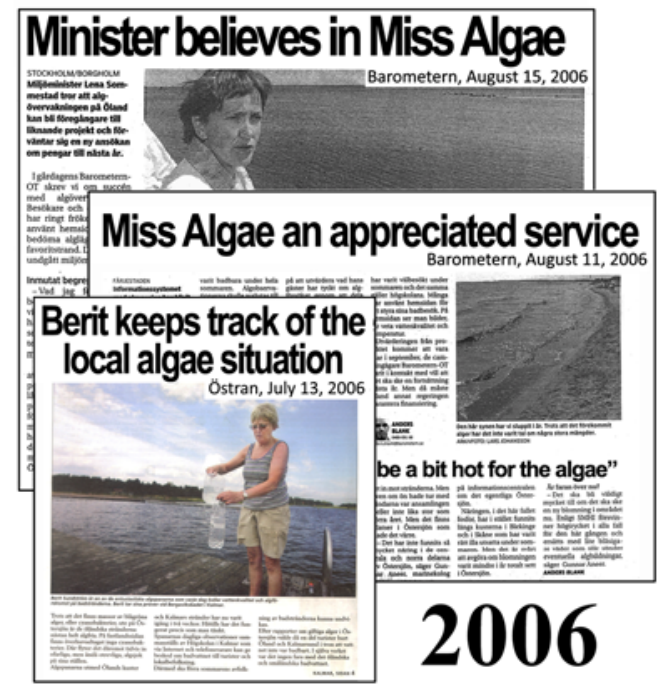

Figure 4. Positive newspaper headlines from 2006.

\section{IMPACT OF THE PROJECT ON STAKE HOLDERS}

During July 2006, for the 17 beaches, between 1000 and 1500 persons/day visited the algae monitoring project home page, www.hik.se/alg. On the mobile service, mobil.hik.se, there were 2618 page views during the same period. For the telephone answering service "Miss Algae" (+49 480446010 ) there were 1569 calls from $1^{\text {st }}$ of July to $15^{\text {th }}$ of August.

The project got a huge amount of positive publicity in the media, both regional and national. The "catastrophic" headlines that during the summer of 2005 scared the tourists off turned to very positive during the summer of 2006 (see Figures 3 and 4). The economical losses of 17-23 million euros in 2005 turned to a profit of 17 million euros in 2006.

During 2007-2009, although only 7-8 beaches were monitored, the project still got a lot of publicity and visitors on the home page (see Table 1).

Table 1. Visitor statistics for “Miss Algae” website, July 2006 - 2009.

\begin{tabular}{lccccc}
\hline Year & 2005 & 2006 & 2007 & 2008 & 2009 \\
\hline Sun hours in July & 290 & 360 & 210 & 340 & 260 \\
\hline Visits on the home page & & 26788 & 8414 & 8998 & 9435 \\
\hline $\mathrm{N}^{\circ}$ of beaches & 17 & 7 & 8 & 7 \\
\hline Visits/beach & 1576 & 1202 & 1125 & 1348 \\
\hline Visits/sun hours & 74 & 40 & 26 & 36 \\
\hline Visits/beach/sun hour & 4,4 & 5,7 & 3,3 & 5,2 \\
\hline
\end{tabular}


Linnaeus ECO-TECH 2012

Kalmar, Sweden, November 26-28, 2012

\section{THE AIM AND THE MOST IMPORTANT RESULTS OF THE PROJECT}

One of the aims of the project was to recruit volunteers and train them in simple research techniques. This to be able to conduct a daily surveillance and in that way show the public how the algae situation was on at least 10 beaches on the island Öland.

1. We managed to recruit and train 25 volunteers 2006. Information from 15 beaches on the island Öland and 2 in Kalmar was daily available before 9:00 a.m. at www.hik.se/alg, at the mobile service mobil.hik.se and at the automatic answering service "Miss Algae" +46480 446010 .

2. The surveillance was successful and we could show that although cyanobacteriae blooms sometimes covered the entire Baltic proper, according to SMHIs remote sensing pictures, these blooms did not in general reach Ölands beaches during July-August 2006-2009.

3. Even when cyanobacterial blooms reached some beaches we could rapidly establish that no or low numbers of the toxic Nodularia spumigena was present.

4. The negative headlines from 2005 turned to positive advertisement for the beaches of Öland 2006 and the positive publicity continued during 2007-2009.

5. The daily information about the different beaches could quickly be transferred to the public by exposition on our home page www.hik.se/alg, at mobile service mobil.hik.se and at the answering machine "Miss Algae". Most important is that the public did trust the information we gave.

6. The volunteers showed to be able to learn fast new techniques, performing with enthusiasm their daily duties, providing the public, through us, very reliable data that restored the confidence in the tourists to return to these beaches.

7. In 2006 most of the volunteers continued sampling once a month throughout the year (in order to build up a long term data-set for water restoration purposes), The volunteers were also very keen in continuing working in the project during the following summers. However, unfortunately due to lack of funds, only Borgholms municipality, on northern Öland, continued to economically support the project the following years. That's why only 7-8 beaches on northern Öland were monitored between 2007 and 2009.

8. Tsai et al, 2005, [2] found that early retirement shortens ones life, so this kind of project involving volunteers is of great social value for people after retirement as well.

\section{ACKNOWLEDGEMENTS}

We are most grateful to all the volunteers, or ALGSPANARNA: "Algal-Watchers" (se below for the names) for their tremendous effort in their daily pursuit to "detect" the cyanobacteria blooms on the Öland coast in all kind of weather, and sampling at such "ungodly" hours. You are forever in our hearts! We are also grateful for the work done during the first year of the "Miss Algae" project by the researchers; Hanna Franzén, Christina Granéli and Catherine Legrand.

\section{The project was financed by:}

The Ministry of the Environment, The Swedish Environmental Protection Agency, Sparbanksstiftelsen Öland, The County Board in Kalmar County, Kalmar University, Swedish Agency for Economic and Regional Growth (Nutek), the Regional Council in Kalmar County, ÖlandsTurist AB, ÖlandsCamping, Borgholm and Mörbylånga municipalities 


\section{Volunteer "Algal-Watchers"}

Bengt Andersson, Allan Bachér, Ann-Margreth Bachér, Anders Barkewall, Solweig Bejerstrand, Stefan Carlsson, Anton Eriksson, Sigurd Figoni, Birgitta Gerlofsson, Hans Gerlofsson, Bror Gustavsson, Henrik Hedén, Pelle Holmberg, Eva Hultenheim, Johan Hultenheim, Harald Janson, Viveka Johansson, Örn Johansson, Parry Jonsson, Charlotte Karlsson, Stefan Lundqvist, Emmelie Nilsson, Carl Gustav Olderius, Björn Rosén, Arne Runsten, Anna Sandström, Nanna

Serrander, Berit Sundström, Lasse Sörenson, Frida Villius, Sven Åhlin, Kajsa Öhman

\section{REFERENCES}

[1] Swedish Meteorological and Hydrological Institute (SMHI), "The Algae situation"homepage: http://www.smhi.se/en/Weather/Sweden-weather/the-algae-situation-1.11631

[2] Tsai, S. P., Wendt, J. K., Donnelly, R. P., de Jong, G., Ahmed, F. S., 2005. Age at retirement and long-term survival of an industrial population: prospective cohort study. British Medical Journal, BMJ, doi: 10. 1136/bmj. 38586.448704.E0 